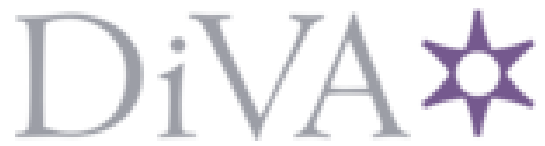

http://www.diva-portal.org

This is the published version of a paper published in Geografiska Annaler. Series B, Human Geography.

Citation for the original published paper (version of record):

Eriksson, M. (2008)

(Re)producing a "peripheral" region: Northern Sweden in the news

Geografiska Annaler. Series B, Human Geography, 90(4): 369-388

https://doi.org/1468-0467

Access to the published version may require subscription.

N.B. When citing this work, cite the original published paper.

Permanent link to this version:

http://urn.kb.se/resolve?urn=urn:nbn:se:umu:diva-19636 


\section{(RE)PRODUCING A “PERIPHERAL” REGION - NORTHERN SWEDEN IN THE NEWS}

by

Madeleine Eriksson

ERIKSSON, M. (2008): '(Re)producing a "peripheral” region northern Sweden in the news', Geografiska Annaler: Series B, Human Geography 90 (4): 1-20.

ABSTRACT. Building on theories of internal orientalism, the objective of this study is to show how intra-national differences are reproduced through influential media representations. By abstracting news representations of Norrland, a large, sparsely populated region in the northernmost part of Sweden, new modes of "internal othering" within Western modernity are put on view. Real and imagined social and economical differences between the "rural North" and the "urban South" are explained in terms of "cultural differences" and "lifestyle" choices. The concept of 'Norrland' is used as an abstract essentialized geographical category and becomes a metonym for a backward and traditional rural space in contrast to equally essentialized urban areas with favoured modern ideals. Specific traits of parts of the region become one with the entire region and the problems of the region become the problems of the people living in the region. I argue that the news representations play a part in the reproduction of a "space of exception", in that one region is constructed as a traditional and undeveloped space in contrast to an otherwise modern nation. A central argument of this study is that research on identity construction and representations of place is needed to come to grips with issues of uneven regional development within western nations.

Key words: internal orientalism, news representations, regional development, Sweden, Norrland.

\section{Introduction}

All nations identify "weaker" and "stronger" regions within the own nation. "Weak" regions are often characterized by, for instance, low economic growth, and high levels of out-migration and unemployment. Research on the representations of such weak regions within Western nations shows that the people residing in these places are often described in media, politics and popular culture and elsewhere as stagnant, traditional and backward (Jarosz and Lawson 2002; Moe 2002; Jansson 2003; Paulgaard 2008). As a result, the problems within these areas are implicitly blamed on the people living there.

Yet, despite a very large literature on the subject of regional development research (Pred 1967; Storper 1997), few studies have acknowledged identity construction and representations of place as influ- ential in the making of Western national peripheries. This may be why researchers such as Barnes et al. (2007, p. 33) can claim legitimately that 'ethnographic depth in economic geography remains illusive'. In the same manner one might state that research with ethnographic depth rarely engages in issues of economic development and that this research to a larger extent has focused on non-Western nations (for a recent example, see Farbotko 2005). It is as if culture and economy are still treated as independent and separate phenomena in geographical research (see Barnes 2003; Schough 2008).

The point of departure of this study is that representations are of importance; they have real material consequences and may, for instance, influence employment rates, financial investments, population flows and industrial reforms. Regional policies and processes of regional restructuring shape and are shaped by geographical imaginations of what places are and should be, by norms of spatial justice and representations of different actors; their capabilities, rights and obligations.

This being the case, a central argument of this study is that a complementary set of tools is needed to come to grips with issues of uneven regional development within nations. By way of giving Swedish examples and by drawing on concepts of space, place, power and difference, the objective of this study is to show how intra-national differences are reproduced through influential media representations. Building on theories of internal orientalism, the aim of this contribution is to add to our understanding of the recurrent and concurrent construction of spaces and people of exception (Agamben 1998; see also Gregory 2004) within countries that so far have been considered as practically exempt from injustices and inequalities such as racism and class divisions, nations that in the popular geographical imagination are viewed as "modern welfare states".

Different from studies focusing merely or predominantly on various one-way representations of 


\section{MADELEINE ERIKSSON}

the "others" (e.g. Jarosz and Lawson 2002; Jansson 2003), this study emphasizes the importance of the reproduction, resistance and reworkings of representations, by elites as well as by others. Moreover, this study aims to uncover strategies of "internal othering" distinctive to modern welfare states. Related research on England (Woodward 1996), Italy (Moe 2002) and the USA (Jarosz and Lawson 2002) view modernity as a system of differentiation and social reproduction which itself creates or else contributes to the construction of peripheries; even so, all regions and places are (re)produced within very different national contexts and discourses, producing very different geographies.

Researchers such as Ehn et al. (1993), Pred (2000) and Schough (2008) suggest that the Swedish self-image is made up of imaginations of being the most equal and just nation in the world. I suggest that weak regions in Sweden are constructed in contrast to this exalted national self-image and in contrast to a relentless construction of national distinctiveness. This means that the construction of peripheries within Sweden involves some general characteristics, but also that these representations take very specific forms. Hence, the construction of "spatial others" within Sweden involves a paradoxical form of representation that inevitably needs to reproduce a national self-image of being the most modern and equal of nations. By abstracting representations of a Swedish region with a colonial history, and a present overshadowed by regional development policies, new modes of internal othering within a modern Western society are put on view.

The geographical focus of this article is Norrland, a large, sparsely populated region in the northernmost part of Sweden. Representations of Norrland in the media, in research, in popular culture and by politicians have been criticized for being incomplete, to a great extent focusing on rural deprivation (Persson 1990; Hansen 1998; Öhman 2001; SOU 2004). Yet the meanings of these representations have received little attention from scholars to date. This article discusses geographical imaginations of the peripheral North that are reproduced, reworked and resisted in different settings and times, thereby reproducing asymmetrical power relations.

News media is one important source of information that contributes to creating the geographical imagination of Norrland; the ways people come to understand the region and how they situate themselves in relation to it. News media affects perceptions of place on a daily basis in a variety of ways, for example, through news reporting and reports on policy-making. It may be seen as a 'space of action' that 'affects the distribution of resources and the life of the people in the regions' (Paasi 2002, p. 805). The news media encompasses a discursive practice that contributes to what we see in the world and how we perceive it; all representations emphasize certain characteristics of a place at the expense of other characteristics. This implies that all representations are incomplete pictures of a place. Hence, it is crucial to emphasize that representations are always political, in the sense that representations work by reinforcing conceptualizations of, for instance, a place that legitimize certain uses and prohibit others (Massey 1993; McDowell 1999).

Through the use of critical discourse analysis of Swedish newspaper texts collected from the leading daily newspaper Dagens Nyheter, I examine a body of media representations of Norrland and the people living in Norrland (norrlänningar or Norrlanders) which suggest understandings and imaginations of Norrland that are likely to influence and reinforce existing views on the region, the people who live there and the choices they make. As such, this work will explore how the journalistic practices of news-making play a part in the discursive construction of Norrland as a "space of exception" within an otherwise modern nation.

I start by introducing the relevant theoretical perspectives on the (re)production of space and place and also the historical context of Norrland. I then, proceed to discuss the politics of representations, media as a producer and reproducer of discourse, and the methodological location of this study. This is followed by an application of discourse analysis to the chosen material and the findings this analysis yields. I conclude by discussing the significance of the news representations of Norrland.

\section{The spatial other}

To study the meanings of the representations, I will draw on the work of critical geographers (Massey 1993, 1994; Pred 2000, 2004) who assert that all social relations are spatial, and that this is of significant importance. In other words, social relations do not exist, nor are they best understood in some abstract purity. Instead, they must be understood relationally and situationally in both space and time, and in terms of a variety of spatial scales. Hence, it is of importance where things take place to understand what they are. The relational per- 
spective on place implies that place can help define another place by being seen as its contrasting image, idea or experience (Said 1978; Massey 1993), for instance, by producing dualities such as ruralurban, modern-traditional and centre-periphery. These dualities and relationships are likely to reinforce spatial and socio-economic hierarchies. The place becomes a sense of identity and the representations become social facts and thereby produce real material and relational consequences, regardless of whether the representations are true (Pred 2000).

The construction of places and people as distinct and different is a common theme within the wide spectra of social sciences. Postcolonial research commonly addresses the Westernized representations of non-Western cultures (Gregory 1995). This study differs from such research in that it focuses on the construction of the others within a nation, constructions of otherness that reinforce regional differences.

Hechter (1975) offers a theory of internal colonialism; he examines the construction of the "postcolonial" British nation and unravels enduring internal economic colonial structures. Hechter suggests that internal colonialism (re)produces unequal rates of exchange between urban power centres and peripheral hinterlands within the nation. The lack of sovereignty within the internal colony produces a contingent development which limits the economic welfare and cultural integrity of the region. According to Hechter, this is expressed by the reproduction of hierarchical cultural divisions of labour on the individual level.

Jansson $(2003,2005)$ builds on the theory of Hechter, adding a spatial perspective by suggesting that the (re)production of the urban-rural dualism within a nation is an important feature in questions of marginality. This is so as it obscures class divisions and results in practices of internal orientalism. Thus, Jansson examines the construction of American national identity within the context of the discourse of internal orientalism, and suggests that "the South" is construed as a "space of racism", in contrast to "America" with opposite values.

Following Jansson, I argue that similar practices are of significance in portrayals of Norrland as the most rural, traditional and problematic region in Sweden. Jansson (2003) points out that the case for the spatial other within the nation differs from the other of the Orient. The other within the state may have a sense of belonging to the nation and ought to have more of a say in the national debate and thereby the rights and power to resist and rework the representations. Jansson (2005, p. 267) further argues that this means that representations of the othered region 'will be complemented by positive representations'. However, I will argue that the dynamics of internal othering are much more complex, and this is especially so within nations where modernity is considered a national characteristic. Here the internal spatial others of the modern welfare state are caught up in a situation of dependency which forces them to reproduce negative representations of the region. Furthermore, the representations of the north of Sweden are contextual and relational; in international contexts Swedes are, for instance, proud to represent northern Sweden as typically Swedish (Sörlin 1988).

More than merely applying the theory of internal orientalism to a region where it has not been applied before, this study seeks to contribute to an increased understanding of how the internal others are given voice but at the same time are silenced. Analysing a national newspaper I expect to find various voices, including the voices of the internal others. By positioning the internal othering in the context of the discourse of modernity, seen as a system of differentiation and a system of social reproduction, I suggest that the (re)production of class and urban-rural dualism are important features of internal orientalism within societies that are characterized as modern. This is so as ideas of class and geographies become enmeshed and obscured by selective memories, discourses of modernity and constructions of "cultures" and "lifestyles".

Since the mid-twentieth century, Sweden has successfully marketed its image as a progressive and modern nation where equality persists and racism, sexism, class boundaries and other conflicts are long gone (Ehn et al. 1993; Pred 2000). It may be argued that this self-image has the potential of obscuring the uneven distribution of the processes of modernization between people and places across Sweden (Pred 2000). In the shaping of the modern Swedish nation, Norrland is represented as a rural, subordinate section of the state so as to produce a national identity with desirable modern and urban characteristics. Hence, rural areas within Sweden not only have connotations of traditional economic structures but also traditional social patterns with traditional norms and values. The urban has come to stand for progress and the rural for regression (see e.g. Ehn et al. 1993).

Within this field of research, scholars such as Little (1997) who focus on other western geogra- 


\section{MADELEINE ERIKSSON}

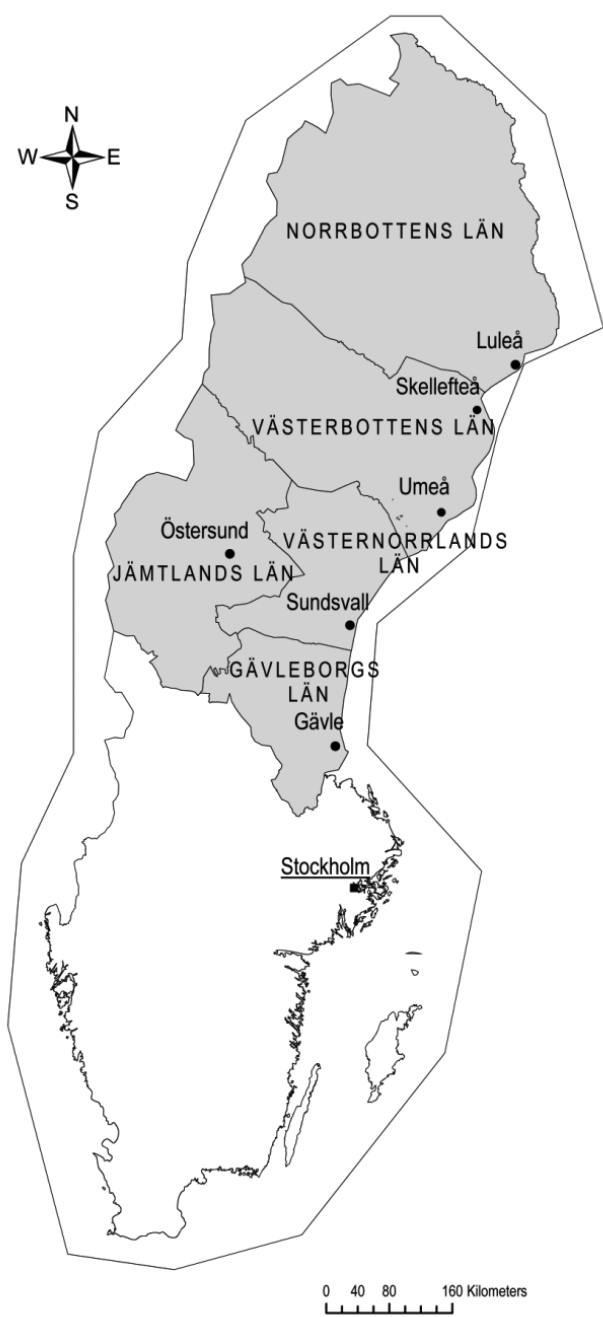

Fig. 1. Norrland.

phies show how particular socio-cultural identities are bound up in constructions of the rural. Woodward (1996) has investigated issues of "deprivation" as a constructed feature of the rural other in England and how urban-rural dualism was strengthened in the course of industrialization and modernization.

Conversely, rural areas may also be described with all the positive attributes lacking in a city, such as authenticity, serenity and order (Halfacree and Boyle 1998). The positive qualities of the rural are often associated with nature and landscape. Positive representations of the rural typically include rurality close to metropolitan areas or the rural as a holiday destination, and negative representations by and large concern remote rural areas and the rural populations as traditional and stagnant.

Relationships based on ideas of spaces of modernity do not stop here, however. Previous research also highlights the response from those made subject to the representations resulting from the process of othering. In addition to actions taken and strategies formulated on the (unwarranted) assumption that the representation of the other is in fact true, within the subordinate region itself, strategies of resistance may be formulated in direct response to imposed identities (Hechter 1975; Jansson 2003,2005$)$. What we see is a constant struggle between discourses to gain hegemonic status. The resistance of representations may be expressed very differently, often by way of everyday conversations and occasionally by establishing a local organization. It is about constructing alternative representations. The existence of a counter-argument does not necessarily imply the existence of a strategy of resistance in the strictest sense, but it may imply the existence of a wish to rework the representations. The truth or the taken for granted that underlies the representation of the other is contested in the sense that representations are reworked and resisted, that there are other representations available, be they equally or more (less) correct, perhaps equally partial.

\section{Norrland as a category in the geographical imagination}

Regions, their boundaries, symbols and institutions are hence not results of autonomous and evolutionary processes but expressions of perpetual struggle over the meanings associated with space, representations, democracy and welfare.

(Paasi 2002, p. 805)

Neither from a physical-geographical nor from an anthropo-geographical point of view is Norrland a natural, sharply defined territory.

(Ahlmann 1921, p. 98)

Norrland, like any other region, is constructed via governmental logics and, as for any other place, the geographical imaginaries of Norrland have altered over time. In this article, Norrland refers to the five most northern counties of Sweden - Gävleborg, Västernorrland, Jämtland, Västerbotten and Norrbotten - which together comprise about 60 per cent of the territory of the country. Nowadays, this 
is the official and most established definition. Furthermore, I use northern Sweden as synonymous with Norrland.

Straightforward as this definition of Norrland seems, the concept itself may be regarded as difficult to utilize. The term is frequently used to represent several counties that are of a considerable size and consist of fifty-four municipalities that, in turn, differ in terms of such aggregates as unemployment rates, net migration, population and labour markets. There are not merely considerable differences between the five counties of Norrland, but also between the municipalities within these counties. Today, Norrland has approximately 1.2 million inhabitants out of the total Swedish population of approximately 9.2 million (SCB 2008). Most of the population in Norrland lives in the coastal areas, which leaves large inland areas largely uninhabited. As a result, there are wide differences in terms of population and economic and social development between inland and coastal areas (see Bylund (1966) on this subject).

Norrbotten in the north and Jämtland in the west have the smallest population numbers and the lowest population density in Norrland. However, it is important to emphasize that some of the counties consist of both dynamic and growing cities also in relation to cities in the middle and south of Sweden. The counties in Norrland also differ when it comes to unemployment rates; especially when comparing municipalities within the counties, the lowest unemployment rates are to be found in the coastal areas of Norrland. As regards counties, Norrbotten and Gävleborg are in particular suffering from high unemployment rates (SCB 2008) ${ }^{1}$. The counties of Norrland have large numbers of people receiving sickness benefit; thus, if analysed at the level of municipalities and controlling for gender, age and industry, we discover a much more complex pattern. For example, one of the municipalities in Norrland, together with two other municipalities in the south, has the smallest amount of people receiving sickness benefit (SCB 2004).

The use of Norrland as a category is often a source of discontent among those living in Norrland, since it generalizes across a large geographi$\mathrm{cal}$ area without taking into consideration the nuances and differences within the region (Öhman 2001). Said (1978,p. 255) calls this a 'summational statement': generalizations are made across wide geographical areas and the entire population is in all important respects regarded as homogeneous. Paasi (2002, p. 805) suggests that the political and economical elite has the power to produce representations of a region and to gradually construct the reality they suggested in 'things and words'. Thus this is also a historical process and, therefore, in order to understand the construction of Norrland we should take the history of the region into consideration.

For a long time Norrland, to the extent that it featured at all, was no more than an abstract construction to most Swedes; it was intangible, undiscovered, practically uninhabited and incredibly large. Subsequently, at the end of the 1600 s, the Swedish state started to encourage the colonization of the interior parts of the region. The motives preceding the colonization of the inland areas and the most northerly parts of Sweden were to increase the nation's cultivated land and tax base, provide a workforce for the expanding wooden and mining industry, and secure Lapland as a Swedish territory (Sörlin 1988).

As industrialization accelerated in the mid-nineteenth century, the notion of Norrland changed dramatically. Sörlin (1988) describes the identity of the nation at that time as dependent on the developments in science, art, technique and production which, in turn, were dependent on the rich natural resources in Norrland. However, projecting an image of Norrland as Sweden's West Indies and Sweden's Gold Coast indicates that Norrland was still considered as separate from the rest of Sweden and was first and foremost represented as a colony where nature had been conquered (see e.g. Balgård 1970). Thus, by the nineteenth century and in the spirit of orientalism and Social Darwinism, not only the Sámi people but also the Finnish-speaking Swedes next to the Finnish border were considered and treated as inferior to the "Swedish race" (Elenius 2006). Indeed, historians such as Mörner (1965) and Elenius (2006) suggest that the representations of the Sámi people and parts of Norrland in the Swedish colonial discourse were analogous to the contemporary national and international colonialist discourse justifying brutal colonization all over the world.

The discourse of Norrland depicting it as a remote rural area and later as a source of natural resources has in a postcolonial fashion created tensions between the region and the central government. Since the colonization of the area, critical commentators in Norrland have claimed that the profits gained from the mining and forestry industries did not benefit the region, but were sent to the urban south (Balgård 1970; Bäärnhielm 1976). 


\section{MADELEINE ERIKSSON}

As Norrland became a target for industrial restructuring during the post-Second World War period, accounts about Norrland have been marked by pessimism. Following the concern, expressed during the 1940s, that the forest regions (which includes most of Norrland) were losing labour to areas where more attractive jobs were available (Wallander 1948), and subsequently that no jobs were available locally, depopulation, industry closedowns and out-migration have become well-known themes in everyday conversations, in mass media, popular culture and politics. The modernization process, including industrialization, urbanization and the decline of agrarian self-sufficiency, had an apparent effect on rural areas within many nations, for instance, Italy (Brunori and Rossi 2007) and England (Massey 1984). In Sweden, when unemployment set in followed by out-migration, the major migratory flows remained within the region, and people from the inland areas of Norrland moved primarily to northern urban or semi-urban areas (Hansen 1998; Håkansson 2000). A new regional policy for Sweden was defined in the mid-1960s, with the explicit aim of increasing the economic growth of the so-called assisted areas, mainly northern Sweden (Sundberg and Öström 1982). According to Bylund (1966), the regional development programme was a failure since the government neglected to make a distinction between the inland areas and the coastal areas of Norrland. Yet, since the mid-1960s, regional policies have been associated with Norrland and have been subject to controversy and debate among politicians and academics as well as in everyday conversations, popular culture and media.

\section{Media discourse, the journalistic field and practices}

In media theory, there is a consensus that news media does not provide any perfect reproduction of reality or a logical consequence of an event that is newsworthy in its own right; rather what it presents is instead seen as a social product. The consensus also entails the argument that mass media as a social product plays an important role in public life (Van Dijk 1988; Bell 1991). Through the descriptions of certain events or proceedings, mass media have the potential to control the political agenda, as well as everyday conversations between friends and co-workers (Van Dijk 1988).

Bourdieu (1996) argues that the competition within the journalistic field generates a lack of in- terest concerning processes and nuanced changes. The hunger for headlines is satisfied by the spectacle, not by serious political issues. For this reason, categorizations, generalizations and stereotyping are the most effective tools in the making of a headline.

One way of theorizing and analysing the tangled relations of discursive constructions of Norrland in news media is offered by critical discourse analysis. Critical discourse analysis has its origin in critical linguistics and goes beyond the mere description of discourse to explanations of how and why certain discourses are produced. Analysts such as Fairclough, Wodak and Van Dijk focus on language as a means of social construction. Thus, Fairclough (1992) argues that discourse is not only a product of social processes but that discourse also emerges out of the reproduction of these processes. Such research aims to reveal the socio-political or sociocultural ideologies that have been well established and accepted in discourse over time. In short, the analysis is a way of revealing how power relations are constructed through and in discourse. This goes back to earlier theorists such as Volosinov (1986), who argued that rather than reflecting reality, language should be seen as refracting it through the lens of social struggle. For Volosinov, this ideological aspect of language did not only apply within politics, education and religion, but is just as important in the apparently trivial, casual conversations of everyday life (Wetherell et al. 2001).

According to Fairclough (1992), discourse may be understood in three ways: discourse perceived as text where the emphasis is on written and spoken text, discourse as practice where the focus is on processes through which text is produced, distributed, received, reworked and resisted, and finally discourse as a social practice where it is examined as part of broader movements in society. These definitions do not suggest that such meanings of discourse as text, practice and social practice are easily distinguished. The different ways in which discourses work, and may be understood, are mutually enmeshed and in reality hard to disentangle from each other.

The analysis of intertextuality is a way of perceiving how the texts are apt to be received, reworked and resisted. The presupposition of a text may be regarded as part of its intertextuality. We presuppose there to be other representations supporting the meaning of the text we are producing or consuming (Fairclough 1995). Fairclough is primarily concerned with written and spoken texts; 
however, the understanding of a place, person or event in this article does not depend on a closed system of texts but on all kinds of representations and discursive practices.

Although representations in news media are important, they are not in any way sufficient on their own for the mapping of the discourse of Norrland in which representations are (re)produced, received, reworked and resisted. Other media such as film and ICT as well as literature, art and politics are part of the everyday workings of discourse. News representations are only part of a wider discursive network constructing popular geographical imaginations of Norrland. Many scholars have stressed that national and regional identities are not only reproduced within politics, education and religion but also in the apparently trivial, casual conversations and actions of daily life (Billig 1995). Political, scientific, literary and popular discourses are interwoven and apparent in news representations contributing to the construction of Swedish national and regional identities.

The purpose of such analyses is to highlight the interaction between social structure and discourse. Thus, the analysis that follows seeks to understand why certain texts are produced and how institutional and professional logics contribute to the ways in which language is used in news, and how these texts contribute to the construction of Norrland.

\section{Analysing news discourse on Norrland}

Since it is necessary to restrict the empirical analysis in time as well as space, it is limited to the years 2000 to 2004 . These years may be characterized as a recession and the period also saw a referendum on joining the European monetary union, the latter of which confirmed a division within the nation into the EU-positive south and the EU-negative north (SCB 2005). Another relevant issue during the time period in question is the ongoing construction of a high-speed railway between Västernorrland and Västerbotten. This project may be seen as part of Swedish regional policies and has received a great deal of criticism from other parts of the country.

Drawing on previous research concerning news representation by Wodak and Chilton (2005) and Van Dijk (1988), the news representations are analysed in terms of textual features. These are part of the representations and highlight the journalistic practices used and the choices made when writing news articles. The starting point of the analysis is to identify textual features relevant to this study: (1) topics, (2) labelling, and (3) analysis of processes and participants.

The news was selected from the database Presstext that includes news articles from Dagens $N y$ heter $(D N)$. The articles, which are listed in the Appendix, were found in two searches. First, sixtyone articles were found using Jämtland, Gävleborg, Norrbotten, Västerbotten and Västernorrland as geographical key words. In a second search, I used Norrland as the geographical key word resulting in thirty-eight articles. There are obvious difficulties with this selection. The county is the largest administrative unit but only one of many geographical categories. Different geographical categories have different meanings and are likely to be mentioned in different settings. For instance, articles about non-administrative regions such as the province (landskap) are less likely to deal with matters of, unemployment or regional policies. Similarly, the municipality (kommun), the smaller administrative unit, would yield information on a more detailed geographical scale. The search of articles on Norrland might have resulted in an overrepresentation of articles that underline generalizations. Moreover, not every article about Norrland is included; it is possible for a place to be discussed without being explicitly mentioned. For example, articles concerning the Sámi people or the mountain range are likely to be associated with Norrland. Words have metonymic functions, language has multiple meanings and it is common for people to take one well-understood or easily perceived aspect of something and use that aspect to represent either the thing as a whole or some other aspect or part of it. The articles analysed are by no means a complete coverage of what has been written about Norrland between the years 2000 and 2004. Another limitation regarding the analysis concerns the use of the Presstext database. The database does not include information about the size of headlines, images and location of the articles within the specific newspaper; for these reasons these aspects have not been analysed.

$D N^{2}$ was selected, as it is the largest Swedish daily newspaper and is regarded as one of two leading quality newspapers in Sweden. $D N$ is a national paper but, at the same time, it may be perceived as a Stockholm one; the editorial staff located in Stockholm inevitably present viewpoints marked by this fact. The newspaper has a daily circulation of approximately 345000 and three-quarters of the readers live in the Stockholm area (DN2007). Despite its relatively narrow range and target group, it may be 
MADELEINE ERIKSSON

Table 1. Number of articles $(\mathrm{n}=38)$ about various topics concerning Norrland.

\begin{tabular}{lc}
\hline Topics & No. of articles \\
\hline Regional subsidies/EU funding & 16 \\
Business & 7 \\
Migration/depopulation & 5 \\
Public transport/planning & 4 \\
State interventions & 2 \\
Weather & 2 \\
Health & 1 \\
Culture & 1 \\
\hline
\end{tabular}

Source: Presstext (2000-2004).

argued that $D N$ has an institutionalized position within Swedish society; it is a major national forum for debate for powerful and influential actors. What is written in $D N$ is not only picked up by other media and distributed to a large share of the Swedish population, it also reflects how regions - centres and peripheries - are talked about and looked upon by representatives of the political and economic elites. It (re)produces conditions for political and economical decisions. For this reason, the representations of Norrland in $D N$ are particularly significant.

\section{Norrland in the news: sparsely populated areas, subsidies and depopulation}

What Fairclough (1995) calls presupposition relates to meanings in the text that are taken for granted - a collective imaginary that is reproduced and reconstructed and not critically revised. It is taken for granted by $D N$ journalists that Norrland is the appropriate term to use for the geographical area in question. In the same way, Norrlanders and "sparsely populated areas" are presupposed. The counties of Norrland are frequently defined as sparsely populated without acknowledging the variations within counties and between various areas. In the material concerning Norrland analysed, it is consequently presupposed that Norrland is a region with problems and that action must be taken to solve those problems. Furthermore, the idea of Norrland as a region of vast out-migration is also taken for granted, yet rarely substantiated by specifying areas or referring to relevant research. Similarly, the surplus of men in the region is taken as a fact.

As a consequence of limited space and time and the selectiveness in newsmaking, some topics are widely discussed and others are ignored (Bourdieu 1996). Analysing which topics are reported on offers a way of mapping the domain in which Norr- land is represented and provides an indication of journalistic practice regarding what is considered newsworthy. The topic should catch the interest of and motivate the reader to read the news and regard the event as newsworthy. The best-selling news is presented in the headlines and in the lead.

I examine different topics and domains in the news texts about Norrland $(n=38)$. As articles were published on only a few topics, these consequently gain weight in the representation of Norrland. Five of these articles explicitly concerned migration or/ and depopulation. All these articles to varying degrees also discussed regional subsidies to Norrland, which was the most common overall theme. Twenty-one of the thirty-eight articles concerned migration, depopulation and/or regional subsidies and EU funding to Norrland (Table 1). Thus, in $D N$, Norrland seems to be primarily represented as a region dependent on subsidies. The frequent occurrence of these topics establishes them as legitimate domains for reporting about Norrland.

Articles about a legal action or legislation are written so as to suggest that tensions between Norrland and the policy-makers in Stockholm or Brussels are taken for granted. This order of discourse becomes a domain where Norrlanders (as quoted in the articles) resist and rework what they experience as unfair news representations:

(1) Vi i norr störs av den debatt om närande och tärande regioner som har uppstått kring förslaget om kommunal skatteutjämning. Det är inte korrekt att Stockholm får bidra till välfärden i Norrland.

( $D N, 16$ February 2004 , letter to the editor from politicians in the counties of Norrland)

We in the north are disturbed by the debate regarding regions that draw on the reserves and regions that build up the reserves which has 
emerged due to the proposal for tax equalization between municipalities. It is not true that Stockholm contributes to the general welfare in Norrland.

(2) Nu ska Stockholmarna få svar på tal efter den senaste tidens debatt om skatteutjämningen.

(DN, 21 November 2003, news article concerning an initiative by politicians in Norrland to provide evidence of Norrland as a productive region)

Now the Stockholmers will get tit for tat on the recent debate concerning regional subsidies.

When writing about regional redistribution and subsidies, the journalists primarily emphasize the large number of welfare recipients and the demand for more subsidies to Norrland. The (re)produced divide between Stockholm and Norrland along with a liberal use of summational statements make it seem as if Norrland receives economic transfers and subsidies at the expense of Stockholm. One article goes so far as to describe regional subsidies as a result of the Norrlanders' preferred 'traditional lifestyle':

(3) Fast det är inte bara de själva [Norrlänningarna] som betalar. Som många irriterade nollåttor numera påpekar är de också medfinansiärer av den traditionella norrländska livsstilen. (DN, 28 April 2004, editorial)

But it is not only they [the Norrlanders] who pay. As many annoyed Stockholmers nowadays point out, they are also financing the Norrlanders' traditional lifestyle.

Here, Norrland and Stockholm are constructed relationally. The simplifications and stereotyping made by journalists and participants in the debate, Stockholmers and Norrlanders claim, are apparent. Norrland is constructed as a weak, subordinate region with irresponsible and passive citizens or as a mistreated and exploited region. In this representational process, Stockholm becomes a metonym for modernity and executive power. These representations are reproduced by journalists and Stockholmers as well as by Norrlanders themselves; for Norrlanders, the construction of Norrland as an exploited region might be an expression of resistance; at the same time, the construction of Norrland as a weak region may be a way of achieving certain political goals.
The topic of depopulation stresses the great number of people leaving rural parts of Norrland. Two articles specifically concerned women who leave Norrland and the resulting surplus of men in the region. The journalists portray girls and women as more resourceful, since they leave Norrland to study or to look for better jobs. The men are regarded as the problem; the macho culture within the working class makes them unwilling to work in sectors other than traditional industry.

(4 Flickorna har däremot anammat medelklassideal. De har expansiva planer och använder skolan för att förbereda sig.

(DN, 28 April 2004)

The girls, on the other hand, have adopted middle-class ideals. They have expansive plans and are using their education to prepare themselves.

(5) Att ett antal unga män i Norrlands inland biter sig fast hemmavid kanske är värst för dem själva ... svårt att hitta en kvinna och bilda familj.

$(D N, 28$ April 2004)

The fact that a number of young men in Norrland cling to their homes might be worst for themselves ... difficult to find a woman and start a family.

One of the articles reviews a report by the Swedish National Rural Development Agency, which reveals that a larger number of young men than young women leave Norrland. ${ }^{3}$

(6) Glesbygden fortsätter att avfolkas. Störst är utflyttningen bland unga män, visar en rapport från Glesbygdsverket, och det är ett trendbrott. (DN, 26 August 2004, news article)

The depopulation of sparsely populated areas continues. The out-migration of younger men is greatest, as shown in a report by the Swedish National Rural Development Agency, and this is a new trend.

The article further endeavours to explain why the men are leaving Norrland. The journalist assumes that the young men are unwilling to move, but are forced to do so because of industrial companies closing down. The men are thereby represented as working class and the women as those voluntarily 
Table 2. Most common topics in articles about the different counties

\begin{tabular}{ll}
\hline Counties & Most common topics \\
\hline Gävleborg & - \\
Jämtland & Tourism $(n=4)$, out-migr. $(\mathrm{n}=3)$ \\
Västerbotten & Tourism $(\mathrm{n}=4)$, reg. policy $(\mathrm{n}=3)$ \\
Västernorrland & Insufficient service \\
Norrbotten & Subsidies $(\mathrm{n}=8)$ \\
\hline
\end{tabular}

Source: Presstext (2000-2004).

moving away in order to study and become part of the middle class:

(7) Trots att männen knappar in på kvinnorna när det gäller utflyttningen står kvinnorna fortfarande för de högsta utbildningsnivåerna.

(DN, 26 August 2004)

Even though the men are catching up on the women in terms of moving, the women are still the ones with a higher level of education [in sparsely populated areas].

Despite the fact that the article concerns the out-migration of men, the journalist reproduces the popular representation (see e.g. Hansen 1998; Nordin 2007) about the serious overall shortage of women in some sparsely populated areas, namely Västerbotten, Norrbotten and Västernorrland:

(8) Det är också där underskottet på kvinnliga invånare är som störst.

(DN, 26 August 2004)

This is also where [in Västerbotten, Norrbotten and Västernorrland] the shortage of female citizens is the greatest.

Out-migration is associated with unemployment and a lack of entrepreneurs. The journalists seem to focus largely on out-migration from sparsely populated areas, not demographic factors or lack of inmigrants, as the problem. Furthermore, the shortage of young people is experienced as a problem in already sparsely populated areas all around Sweden. Youth often move away to study or to find a job; moreover, young women are in general more mobile than young men (SCB 2006).

The disparate representations of women and men in Norrland reveal a discourse of Norrland as a male-dominated society that is stagnant and underdeveloped. Traditional becomes synonymous with working class, and equality becomes a measurement of urban modernity, the existence of middle-class values and progress, things Norrland is said to lack.

In Sweden, as in other liberal Western democracies, the main indicators of modernity - at least at the level of rhetoric, not necessarily in practice are openness and equality regardless of gender, race, class and sexuality (see e.g. Beck 1992). Intolerance and obsolescence become metonyms for the traditional, and consequently for the rural. Even though women in Norrland are described as resourceful actors, taking their destinies into their own hands, they are invisible as voices in this regional debate. By way of representing women as moving away from Norrland and the men there to spaces of modernity and progress, these women are concurrently represented as the symbolic and cultural capital of (modern and urban) men (Bourdieu 2001); they become tools in the construction of urban modernity.

In the analysis of articles concerning specific counties $(n=61)$, as will be developed at some length below, the media representations vary significantly between counties; the majority of the news representations relate to Norrbotten and are, to a greater extent than for other counties, characterized by few topics and negative news (Table 2). When writing about Norrbotten $(n=31)$, the most common topic is 'People in Norrbotten protest against reduced benefits and subsidies' followed by articles about self-governance and Kiruna Partiet, a local party in the county.

(9) Sjukskrivningen används som regionalstöd. Lokala attityder ligger bakom den höga sjukfrånvaron i Norrbotten.

(DN, 18 October 2003, letter to the editor)

Sick-listing is used as regional subsidies. Local attitudes are behind the many sick leaves in Norrbotten. 
Table 3. Number of total articles $(n=38)$ in which Norrland was specified/not specified as county, municipality or city.

\begin{tabular}{lc}
\hline Labelling in text & No. of articles \\
\hline Specified by county & 21 \\
Not specified & 17 \\
Specified by municipality & 1 \\
Specified by city & 0 \\
\hline
\end{tabular}

Source: Presstext (2000-2004).

(10) En viktig förutsättning [för prostitution] är också en traditionell mansroll, som strikt bestämmer vad som är manligt och omanligt. I Norrbotten har denna indelning ett eget begrepp.

(DN, 17 June 2003, editorial)

An important condition [for prostitution] is also a traditional masculinity, which strictly decides what is manly and what is unmanly. In Norrbotten this division has become a concept.

This picture is less pronounced in the writings on the other counties. The most common topics in news articles about Västerbotten $(n=12)$ are tourism and regional policies, but these topics do not dominate to any great extent. The article about Västernorrland $(n=1)$ concerns the insufficient geriatric care in the county. As for Jämtland $(n=17)$, the topics focus on the deterioration of medical services and tourism. Three articles concern attempts by politicians in the county to attract in-migrants to the region, preferably skilled people from Stockholm. The local politicians promote an alternative lifestyle to that of the crowded city; Jämtland is marketed as a mix of the modern and the historical.

(11) Historiskt och modernt [i Jämtland] ska mötas i en vacker förening.

(DN, 14 March 2002, news article concerning a marketing campaign to promote the county of Jämtland, launched with a view to attracting Stockholmers to Jämtland; the campaign takes place at Central Station in Stockholm.)

The historical and the modern [in Jämtland] are to come together in a beautiful union.

The articles treat both particular and general phe- nomena of places in Norrland; thus the focus on negative news is symptomatic. This may be partly explained by what is expected from journalists and their articles. As is well known, a tendency to focus on certain topics, and the competition between the media, tends to result in similar news reporting of the same events rather than a variation in news reporting, and is often characteristic of journalistic practice (Bell 1991).

Rather than focusing the attention on underlying historical and structural factors that contribute to some of the problems faced by the region, the problems are often understood in terms of cultural and lifestyle differences between the north and the south of Sweden. In this way, Norrlanders may be construed as Swedish people of exception and made responsible for the persistence of several of the problems associated with the region, including unemployment and a diminishing population.

\section{Labelling: simply Norrland}

Labelling is not only a descriptive usage of linguistic resources but can be useful in the understanding of the social practices embedded in the communicative situation regarding, for instance, the social and political position of a region or a place. The considered significance of a place or a region may be revealed by the use of definitions and how thoroughly definitions are made.

In this analysis, I counted the occasions when the term "Norrland" was used and when Norrland was specified as, for instance, the county of Västerbotten (Table 3 ). When the headline topic identifies a geographical area $(n=30)$, it is only by using the terms "Norrland" or "the North". In seventeen of the thirty-eight articles, Norrland is not specified anywhere in the text as counties, municipalities or cities. One of the articles identifies the geographical area for the event, by mentioning both the county and the municipality. When specifying a place in Norrland, a county or a municipality, in most cases 


\section{MADELEINE ERIKSSON}

Table 4. Number of articles about Norrland in which the counties, cities and other places are mentioned.

\begin{tabular}{lcc}
\hline Counties & As county & As city/place \\
\hline Gävleborg & 2 & - \\
Jämtland & 7 & 5 \\
Norrbotten & 12 & 12 \\
Västerbotten & 12 & 7 \\
Västernorrland & 6 & 5 \\
\hline
\end{tabular}

Source: Presstext (2000-2004).

it is at the end of the text and a reference to Norrland is made at the same time. In this manner places are positioned to a familiar but abstract space, with well-known connotations and metonyms.

The counties of Västerbotten and Norrbotten are most frequently mentioned, while the southernmost county, Gävleborg, is mentioned in only two of the texts. As for cities or places mentioned within the different counties, Norrbotten is once more frequently represented (Table 4). The province of Hälsingland, which forms part of the county of Gävleborg, is referred to in one of the articles. Cities and places in Gävleborg are not mentioned at all, while the province of Dalsland (further south on the border with Norway), the county of Dalarna (immediately to the south of Norrland) and the ski resort Sälen in Dalarna are mentioned in two of the articles.

In representational statements, the particular often becomes universalized and the universal becomes particular (Said 1979), and they include metonymical functions where words have multiple functions and meanings. Specific aspects of, for instance, Norrbotten are altered to represent the whole region and general aspects of Norrland are constructed to also represent the specific, such as a village, town or county. Certain themes have become vital parts of the region and together create stereotypes. Consequently, the counties, municipalities and towns that most closely correspond to the stereotypes of Norrland are those representing the region. Nowhere in the articles are the large cities in Norrland (e.g. Luleå, Sundsvall, Umeå) mentioned, and this may indicate that these cities not are viewed as Norrland; in contrast, they are more likely to be viewed as urban spaces.

Norrbotten and Västerbotten in the very north and specific places in Norrbotten in most cases appear to represent Norrland. Furthermore, the journalists at $D N$ rarely include the county of Gävleborg in the concept of Norrland, whereas Dalarna
- a forested region not part of Norrland - is included in articles about Norrland as often as is Gävleborg.

The county of Norrbotten is most frequently written about in terms of county-based articles $(\mathrm{n}=61)$, as well as in articles about Norrland, whereas Gävleborg seems almost invisible as a specific county in $D N$ (Tables 4 and 5). The modest news reporting on Gävleborg and Västernorrland might indicate that few events and actions that the journalists regard as newsworthy take place in these counties. Another explanation may be an inconsistency in the usage of geographical terms and a disparity in the construction of regional identities and regionalism within and across the counties in question.

As already noted above, the county of Norrbotten has frequently been mentioned in the media since the end of the 1990s when the political party Kiruna Partiet was founded. This party is a regional party focusing on Norrbotten, but also on Norrland as a whole. The party has had rather controversial ideas and it has successfully made the headlines in $D N$ and other media by using provocative rhetoric.

(12) [Kiruna Partiet] Hotade rikta kanonerna mot Stockholm efter beslutet om nedläggning av regementet I 22 [i Kiruna, Norrbotten].

(DN, 24 October 2001, news article)

[Kiruna Partiet] Threatened to aim the guns at Stockholm after the decision to close down the I 22 regiment [in Kiruna, Norrbotten].

Jämtland has a tradition of regionalism and has developed a strong regional identity throughout history. The (mock) Republic of Jämtland was founded in 1963 as a symbolic reaction to governmental policies regarding out-migration from the region. The strong lobby in Jämtland against the European Union has also been well recognized by the media. 
Table 5. Number of articles concerning the different counties in Norrland $(n=61)$.

\begin{tabular}{lc}
\hline Counties & No. of articles \\
\hline Gävleborg & - \\
Jämtland & 17 \\
Norrbotten & 31 \\
Västerbotten & 12 \\
Västernorrland & 1 \\
\hline
\end{tabular}

Source: Presstext (2000-2004).

Two of the twelve articles written about Jämtland concern regional identity, and are written in a satirical and ironic style. One article makes fun of the social democratic local parliament and the scepticism in Jämtland towards the EU:

(13) Göran Persson är utsänd av EU för att utreda vad som händer $\mathrm{i}$ den alltmer slutna Folkrepubliken Jämtland i norra Sverige.

(DN, 2 February 2002, editorial)

Göran Persson [the then Swedish Prime Minister] has been sent out by the EU to investigate what is happening in the increasingly secluded People's Republic of Jämtland in the north of Sweden.

The tendency to write in a satirical or ironic manner also applies to articles written about Kiruna Partiet. Hence, it is important to acknowledge also that these representations are political; regardless of obvious exaggerations and the entertaining style they too reproduce taken-for-granted meanings of places and people.

As already mentioned, Hechter (1975) and Jansson $(2003,2005)$ have noted that people within a subordinate region can come to resist the identity that has been forced on them, thus causing them to mobilize around autonomist or secessionist sentiments. Kiruna Partiet and the Republic of Jämtland may be seen as movements caused by a need to detach oneself from the nation, a need to react against past policies, and to be a regional voice in the national political debate. These movements often attempt to inform about the history and geography of Sweden by stressing the significance of natural resources and a population in Norrland managing these resources. Consequently, these movements, regardless of their public support, play an important part in the identity constructions of the region, the counties and municipalities.
The articles that were found using the five counties as key words may be distinguished from those found in the first search. The articles that explicitly dealt with counties are, in general, longer and more specific but not necessarily more accurate. The counties are often referred to as 'the counties in Norrland' or 'sparsely populated regions'. Sörlin (1988) supports this impression when he writes that Norrland is made synonymous with sparsely populated areas.

Norrbotten and Västerbotten are the counties that get to represent Norrland in $D N$ (Table 5), and it is also these counties that are characterized by the most negative news. Gävleborg and Västernorrland, however, are not necessarily Norrland in the eyes of the journalists, perhaps due to the relatively short distance to Stockholm. Paradoxical enough, it also seems as if the old definition of Norrland, as everything north of the River Dalälven, prevails in some journalists' representations of Norrland. Since this old definition goes back to a time when the land north of the Dalälven was more or less viewed as a terra incognita, those using the definition today might suggest the same.

Norrland is repeatedly represented as an abstract rural area, even though it is a differentiated region with large variations between, for instance, the coast and inland areas. The news representations of Norrland in $D N$ cannot be distinguished from representations of those living there. The problems of the region become the problems of the Norrlanders. Moreover, specific characteristics of Norrland are seen as applicable to the entire region, and any person living in Norrland becomes one with the entire population and its defining characteristics. An alternative way of labelling Norrland could, for instance, have been to depict it as a diverse region, both urban and rural, with areas still suffering from dramatic restructuring of agriculture and industry.

When different places in Norrland are identified and defined it is often to draw attention to opinions other than those of the majority. Yet these expres- 


\section{MADELEINE ERIKSSON}

sions of discontent and resistance are rarely taken seriously by the journalists at $D N$. If anything, resistance is represented as resistance to progress and development. Norrland as indispensable for the development in the rest of the nation is rarely talked about, unless it is brought up by or attributed to participants in the debate originating from Norrland.

\section{Processes and participants in Dagens Nyheter}

The focus in this part of the analysis is on the main characteristics of news articles about Norrland $(n=38)$, and the comparison and identification of the representations of their actions and roles. Halliday (1994) offers several tools for the analysis of text. Drawing on Halliday's method of text analysis, I will examine the structure of the articles in terms of processes and participants. This approach distinguishes between different processes and participants that entail different grammatical relations or semantic diversifications. In short, this transitivity analysis aims at describing participants in news discourse and identifying how the dominant and subordinate agents are constructed, what they do, to whom and with what consequences.

First, I focus on material processes that involve participants' roles as actors (actor role) and affected participants (goal role). I will furthermore analyse the text in terms of relational and mental processes. Relational processes in articles about Norrland concern descriptions and constructions of identity in relation to other geographical areas. The mental processes represent someone's thoughts, ideas or observations. In these processes, one participant is in the role of processing ("sensor") and another is a being "sensed" (Halliday 1994). It can sometimes be problematic to distinguish between different processes and participants, and the articles often include more than one process. My goal here is to outline any general tendency in the representations of Norrland as may exist in the articles extracted from the database and draw attention to the textual choices made by the journalists.

In writing about Norrlanders, the $D N$ journalists represented them as direct actors but, most frequently, Norrlanders are represented as affected by actions taken by the Swedish government (Table 6). Furthermore, the participants are represented differently in terms of personalization and impersonalization of agency. Norrlanders as actors were typically portrayed as personalized participants and referred to in general terms as Norrlanders; sometimes the personalized participant is de- scribed as a united geographical area sharing a common goal:

(14) Norrland slår tillbaka.

(DN, 21 November 2003, news article)

Norrland strikes back.

(15) De fem Norrlandslänen vill.

(DN, 13 December 2002, news article)

The five counties in Norrland want to.

Other actors that appear in the articles are illustrated as impersonalized representatives; in most cases, such as the state of Sweden, different ministries or politicians and institutions in Brussels. Different representatives of the Swedish state are put into the role of actors on twenty-two occasions, as compared to goal roles on three occasions. The personalization of Norrlanders and the impersonalization of representatives from Swedish or the EU establishments indicate an unequal and distanced relationship:

(16) Regeringen förvränger information mellan oss och Bryssel.

(DN, 11February 2001, news article)

The Government distorts information between us [businessmen in Norrland] and Brussels.

Representing issues of Norrland and Norrlanders as something concerning personalized Norrlanders and the impersonalized Swedish establishment, $D N$ journalists depict issues concerning Norrland as matters where Norrlanders and the Swedish establishment adopt opposing positions. It could be argued that the representation of Norrlanders, not only as a group but also as a homogenized group, indicates that Norrlanders are fighting against the system of the majority; consequently, Norrlanders become "othered" and excluded from the majority system. The representation of Norrlanders is focused on their marginalized position and peripheral location, whereas the other actors are represented as the majority located in the centre.

Not surprisingly, Norrlanders are placed as actors in processes involving improving their rights and position. More interesting is the fact that the Swedish establishment is frequently placed as an actor in processes constraining and conditioning Norrlanders' actions, wishes and demands, practically positioning them as opponents to Norrland 
Table 6. Actions and roles by Norrlanders and the Swedish government/officials.

\begin{tabular}{lcc}
\hline & Norrlanders & Government/officials \\
\hline Actors role & 10 & 22 \\
Goal role & 27 & 3 \\
\hline
\end{tabular}

Source: Presstext (2000-2004).

and the Norrlanders. This simplified relationship may be a consequence of incomplete news reporting as well as of the propensity of both Norrlanders and Stockholmers to simplify a complex reality. This is a part of the construction of identity and the construction of difference. The opposition between these roles becomes further established by frequently placing Norrlanders and Norrland in the affected participant role.

Other actors besides those from the Swedish establishment and Norrlanders are impersonalized participants, politicians in Norrland and local politicians in the Stockholm region. In the cases of Norrlanders, they are placed in an actor role and their actions almost always affect the non-Norrlanders in a negative way. The majority of the Swedish population and local politicians in Stockholm are positioned as antagonists against Norrland and Norrlanders in similar ways as in the Swedish establishment.

The use of relational processes in the news texts focuses on descriptions of Norrland and the Norrlander participants. Norrlanders and Norrland are most often described in relation to metropolitan areas, first and foremost the area around Stockholm. Norrland is commonly portrayed as sparsely populated with long travel distances and in need of financial support. Norrlanders are represented as different, such as working class, poor and passive.

The most apparent example of the polarization of Norrland and Stockholm is the debate on regional distribution. The expression 'tärande och närande regioner' (see e.g. quotations 1 and 17) has frequently been used by politicians and journalists, and refers to two diametrically opposed categories of regions: one category that only builds the resources of the state and regions that only draw from these resources; naturally, this is much more complicated in reality. Norrlanders claim that transfers out of the region to Stockholm and other metropolitan areas, in total, go far beyond the subsidies to Norrland, for instance, through large public investments directed to the Stockholm area. In contrast, journalists at $D N$ and representatives from Stockholm and other metropolitan areas point to the comparatively large amount of subsidies per capita which Norrland receives. The representations of Norrland and Norrlanders are contradictory; how they are depicted depends, for instance, on who holds the actor role and the goal role, an example of which is the following quote where a Norrlander's voice is heard:

(17) Stockholm är en tärande region. Nya beräkningar visar att stockholmarna får mest av statens kaka medan norrlänningarna missgynnas. ( $D N, 16$ February 2004, letter to the Editor)

'Stockholm is a region drawing on the resources [of the state]'. New calculations show that the people in Stockholm receive the greatest share of the state's resources while the Norrlanders are disadvantaged.

Or if a member of the Swedish majority system is heard:

(18) För egen del tar jag gärna mitt ansvar för att hela landet ska leva. Men vissa delar av Norrland tycks inte längre leva utan tyna bort.

(DN, 26 April 2004, editorial)

Speaking for myself, I am happy to take my responsibility so that the whole nation will prosper. But certain parts of Norrland do not seem to prosper, they seem to be dying.

Diverse mental processes are used by the different actors. Norrlanders and Stockholmers are placed in agency roles as "sensors" who initiate suggestions, make demands, decide, believe and think (Halliday 1994). Not unexpectedly, the state officials are those who often make "decisions" and put forth "suggestions", while the Norrlanders more often "demand", "want" and "think":

(19) Norrlandsförbundet kräver att Sveriges regering tar ansvar för att en rimlig kollektivtrafik kan upprätthållas i Norrland.

(DN, 30 May 2002, news article) 


\section{MADELEINE ERIKSSON}

The Norrland Association ${ }^{4}$ requires that the Swedish government takes responsibility so that adequate public transportation systems can be maintained in Norrland.

The media articles reveal a difference in the mental processes between the articles' participants. The impersonalized Swedish establishment and state officials are represented as initiating suggestions and the Norrlanders as those being repeatedly "sensed"; that is, being confined to the role of objects for decisions and suggestions.

This analysis shows a variety of patterns in the distribution of agency, affecting and affected participant roles in $D N$. The general trend, however, positions Norrlanders as direct agents in the process of improving their situation. Furthermore, Norrlanders are consistently represented as a deviant and homogenized group. The Swedish establishment is primarily represented as participants restricting Norrlanders' wishes and demands.

\section{Meanings of news representations}

Drawing on theories of internal orientalism and otherness (Hechter 1975; Jansson 2003, 2005), this article suggests a more complex pattern of representational practices and processes than what has previously been described (see Jansson 2003, 2005). It draws attention to the internal othering that is reproduced (but also reworked and resisted) in conjunction with the internal others themselves.

I have examined media representations of Norrland and the people living in Norrland (norrlänningar or Norrlanders). The aim was to show how understandings of Norrland are (re)produced, resisted and reworked through media representations in the Stockholm-based national newspaper $D N$ which may influence, and perhaps reinforce, existing views on the region, the people who live there and the choices they make.

The news representations in $D N$ make particular issues, such as regional development policies, unemployment and out-migration, synonymous with the entire region of Norrland regardless of actual local variation; these representations re-enact the role of the centre (Stockholm) as being in control of the distribution of resources. Politicians and commentators in Norrland are apt to construct Norrland on the one hand as a modern and progressive region and on the other as a region in need of financial support. This may be seen as strategies for reworking and resisting the elite's execution of pow- er, but also to obtain more of the state's resources. The workings of these representations may be traced back to the colonization of parts of Norrland, processes of modernization and to current discussions of regional redistribution programmes.

Norrland and the Norrlanders are often portrayed as weak and placed in relation and opposition to urban places and urban people. The news representations make an urban lifestyle the norm, a way of life that is seen as progressive and modern. Those not fitting these descriptions are construed as others - exceptions, sometimes as old-fashioned, working class, people to joke about, and thus those to blame for existing and non-existing problems resulting from being detached from modernity.

These representations are political and have implications both for people's identities as Norrlanders and for the actual situation in parts of Norrland. Representations contribute to the (re)production of the problems of the inland areas, with, for instance, young people moving to the cities. People everywhere are exposed to representations idealizing the cosmopolitan urban lifestyle; people move to the cities in order to avail themselves of and escape, respectively, the representations that become social reality in both urban and non-urban areas. Modernity here becomes a system of differentiation and a system of social reproduction. Negative representations of people and places cover our view, and categorizations obstruct constructive political measures.

Politicians and researchers interested in uneven regional development within industrialized countries have by and large overlooked the complex representational practices and processes highlighted in this article. As Barnes et al. (2007) suggest, culture studies and economic research should not be regarded as separate activities. Further research on the interplay and making of national peripheries, national discourses and national identities are needed within a wide range of disciplines and research fields. It is about finding alternative ways of representing; by deconstructing dichotomies and discovering and foregrounding things that are normally silenced. In this way critical perspectives on the workings of representations can contribute to an understanding of how spatial difference and regional inequity are reproduced, and play a part in formulating and implementing strategies to attain social change. Without a sensitivity to past and present representations, all attempts by politicians and researchers to improve the conditions of a place, such as the inland areas of Norrland, risk becoming a shot in the dark. 


\section{Acknowledgements}

I would like to thank Gunnar Malmberg, Urban Lindgren and Liselotte Eriksson for valuable comments on earlier drafts of this paper, as well as three anonymous referees for their feedback. The financial support for this study was granted by the Swedish Research Council (Vetenskapsrådet).

\section{Notes}

1. Unemployment rates for the period studied 2000-2004, as well as more recent unemployment rates between the years 2005-2007. Please note that in April 2005 a new EU-harmonized LFS (Labor Force Survey) was introduced. This caused a break in comparability over time, for more information see SCB (2005)

2000: Sweden $4.7 \%$, Västerbotten $4.2 \%$, Norrbotten $6.9 \%$, Gävleborg 7.4\%, Jämtland 5.9\%, Västernorrland 7.0\%

2001: Sweden $4.0 \%$, Västerbotten $3.5 \%$, Norrbotten $6.5 \%$, Gävleborg 6.2\%, Jämtland 5.4\%, Västernorrland $4.9 \%$ 2002: Sweden $4.0 \%$, Västerbotten $3.7 \%$, Norrbotten $6.2 \%$, Gävleborg 5.9\%, Jämtland 4.7\%, Västernorrland $4.1 \%$ 2003: Sweden 4.9\%, Västerbotten $4.2 \%$, Norrbotten $7.3 \%$, Gävleborg $7.5 \%$, Jämtland $4.9 \%$, Västernorrland $4.7 \%$ 2004: Sweden 5.5\%, Västerbotten 5.2\%, Norrbotten $7.5 \%$, Gävleborg 7.0\%, Jämtland 4.9\%, Västernorrland 5.6\% 2005: Sweden $7.8 \%$, Västerbotten $7.7 \%$, Norrbotten $10 \%$, Gävleborg $10.3 \%$, Jämtland 9.1\%, Västernorrland $8.9 \%$ 2006: Sweden $7.1 \%$, Västerbotten $8.3 \%$, Norrbotten $8.7 \%$, Gävleborg $8.9 \%$, Jämtland $7 \%$, Västernorrland $7.5 \%$ 2007: Sweden $6.1 \%$, Västerbotten $5.8 \%$, Norrbotten $7.8 \%$, Gävleborg 6.5\%, Jämtland 6\%, Västernorrland 6.5\% (SCB 2008)

2. The official political position of $D N$ is 'independently liberal'. $D N$ is owned by Bonniers, one of the largest media companies in Northern Europe.

3. This is somewhat remarkable, since young women in rural areas as well as in urban areas in Sweden move to a greater extent than men.

4. Norrlandsförbundet is a lobby organization with approximately 6000 members, taking an interest in and promoting issues related to the northern part of Sweden.

\section{Madeleine Eriksson}

Department of Social and Economic Geography

Umeå University

SE-901 87 Umeå, Sweden

E-mail:madeleine.eriksson@geography.umu.se

\section{References}

AGAMBEN, G. (1998): Homo Sacer: Sovereign Power and Bare Life. Stanford University Press, Stanford, CA.

AHLMANN,H.W.(1921): 'The economical geography of Swedish Norrland', Geografiska Annaler 3: 97-164.

BÄÄRNHIELM, G. (1976): I Norrland hava vi ett Indien: gruvdrift och kolonisation i lappmarken under 1600-talet. Ordfront, Stockholm.

BALGÅRD, G. (1970): Angår det Sverige om Norrland finns? Thule, Stockholm.

BARNES, T.J (2003): 'Never mind the economy. Here's culture', in ANDERSON, K., DOMOSH, M., PILE, S. and THRIFT,
N.J. (eds): The Handbook to Cultural Geography. Sage, London, pp. 89-97.

BARNES, T.J., PECK, J., SHEPPARD, E. and TICKELL, A. (2007): 'Methods matter: transformations in economic geography', in TICKELL, A., SHEPPARD, E., PECK, J. and BARNES, T.J. (eds): Politics and Practices in Economic Geography. Sage, London, pp. 1-24.

BECK, U. (1992): Risk Society: Towards a New Modernity. Sage, London.

BELL, A. (1991): The Language of Media. Blackwell, Oxford.

BERGGREN, H. and TRÄGÅRDH, L. (2006): Är svensken människa? Norstedts, Stockholm.

BILLIG, M. (1995): Banal Nationalism. Sage, London.

BOURDIEU, P. (1996): On Television. New Press, New York.

BOURDIEU, P. (2001): Masculine Domination. Polity, Cambridge.

BRUNORI, G. and ROSSI, A. (2007): 'Differentiating countryside: social representations and governance patterns in rural areas with high social density. The case of Chianti, Italy', Journal of Rural Studies 23 (2): 183-205.

BYLUND, E. (1966): Glesbygdsproblemet - Norrlandsproblemet. Ymer, Umeå.

DN (2007): Dagens Nyheter [online edition]. URL: http:// www.dn.se [accessed 25 June 2007].

EHN, B., FRYKMAN, J. and LÖFGREN, O. (1993): Försvenskningen av Sverige. Natur och Kultur, Stockholm.

ELENIUS, L. (2006): Nationalstat och minoritetspolitik: samer och finskpråkiga minoriteter $i$ ett jämförande perspektiv. Studentlitteratur, Lund.

FAIRCLOUGH, N. (1992): Discourse and Social Change. Polity Press, Cambridge.

FAIRCLOUGH, N. (1995): Critical Discourse Analysis. Longman, London.

GLESBYGDSVERKET (2004): Glesbygdsverkets Årsbok 2004. Glesbygdsverket, Östersund.

GREGORY, D. (1995): 'Imaginative geographies', Progress in Human Geography 19 (4): 447-485.

GREGORY, D. (2004): The Colonial Present. Blackwell, Oxford.

HÅKANSSON, J. (2000): Changing Population Distribution in Sweden - Long Term Trends and Contemporary Tendencies. Kulturgeografiska Institutionen, Umeå Universitet, Umeå.

HALFACREE, K.H. and BOYLE, P.J. (1998): Exploring Contemporary Migration. Addison Wesley Longman, Harlow.

HALLIDAY, M.A.K. (1989): 'Text, context, and learning', in HALLIDAY, M.A.K. and HASAN, R. (eds): Language, Context and Text: Aspects of Language in a Social-semiotic Perspective. Oxford University Press, New York, pp. 44-49.

HANSEN, K. (1998): Välfärdens motsträviga utkant: lokal praktik och central styrning $i$ efterskrigstidens nordsvenska inland. Historiska media, Lund.

HECHTER, M. (1975): Internal Colonialism: The Celtic Fringe in British National Development, 1536-1966. Routledge \& Kegan Paul, London.

JANSSON, D.R. (2003): 'Internal orientalism in America: W.J. Cash's The Mind of the South and the spatial construction of American national identity', Political Geography 22 (3): 293316.

JANSSON, D.R. (2005): “A geography of racism”: internal orientalism and the construction of American national identity in the film Mississippi Burning', National Identities 7 (3): 265285.

JAROSZ, L. and LAWSON, V. (2002): "'Sophisticated people versus Rednecks": economic restructuring and class difference in America's West', Antipode 34 (1): 8-27.

LITTLE, J. (1997): ‘Employment marginality and women's self- 


\section{MADELEINE ERIKSSON}

identity', in CLOKE, P. and LITTLE, J. (eds): Contested Countryside Cultures: Otherness, Marginalisation and $R u-$ rality. Routledge, London, pp. 138-157.

MASSEY, D. (1984): Spatial Division of Labour, Social Structures and the Geography of Production. Macmillan, London.

MASSEY, D. (1993): 'Politics and space/time', in KEITH, M and PILE, S. (eds): Place and the Politics of Identity. Routledge, London, pp. 141-161.

MASSEY,D. (1994): Space, Place and Gender. Polity Press, Oxford.

MCDOWELL, L. (1999): Gender, Identity and Place: Understanding Feminist Geographies. Polity Press, Cambridge.

MOE, N. (2002): The View from Vesuvius: Italian Culture and the Southern Question. University of California Press, Berkeley, CA.

MÖRNER, M. (1965): Latinamerikas historia. Natur och Kultur, Stockholm.

NORDIN, L. (2007): Man ska ju vara två. Män och kärlekslängtan i norrländsk glesbygd. Natur och Kultur, Stockholm.

ÖHMAN, A. (ed.) (2001): Rötter och rutter. Norrland och den kulturella identiteten. Kungl. Skytteanska samfundets handlingar 52, Institutionen för litteraturvetenskap och nordiska språk, Umeå Universitet, Umeå.

PAASI, A. (2002): 'Place and region: regional worlds and words', Progress in Human Geography 26 (6): 802-811.

PAULGAARD, G. (2008): 'Re-centering periphery: negotiating identities in time and space', in BÆRENHOLDT, J.O. and GRANÅS, B. (eds): Mobility and Place: Enacting Northern European Peripheries. Ashgate, Aldershot, pp. 49-60.

PERSSON, L.O. (1990): 'Urbanization processes in peripheral regions in a welfare state', Journal of Rural Studies 6 (4): 4963.

PRED, A. (1967): Behavior and Location: Foundations for a Geographic and Dynamic Location Theory, Part 1. Lund Studies in Geography Series B, Human Geography 27, Lund University, Lund.

PRED, A. (2000): Even in Sweden - Racism, Racialized Spaces, and the Popular Geographical Imagination. University of California Press, Berkeley, CA.

PRED, A. (2004): The Past is Not Dead: Facts, Fictions, and Enduring Racial Stereotypes. University of Minnesota Press, Minneapolis, $\mathrm{MN}$.
PRESSTEXT (2000-2004): PressText Online [online database]. URL http://www.presstext.se/ [accessed 7 September 2006].

SAID, E.W. (1979): Orientalism. Vintage, New York.

SCB [Sveriges Statistiska Centralbyrå] (2004): Ohälsa regionalt perspektiv på ett nationellt problem. Sveriges statistiska databaser [online database]. URL: http://www.scb.se [accessed 6 October 2007].

SCB (2005): Sveriges statistiska databaser [online database]. URL: http://www.scb.se [accessed 4 October 2006].

SCB (2006): Sveriges statistiska databaser [online database]. URL: http://www.scb.se [accessed 5 May 2007].

SCB (2008): Sveriges statistiska databaser [online database]. URL: http://www.scb.se [accessed 1 September 2008].

SCHOUGH, K. (2008): Hyperboré. Föreställningen om Sveriges plats $i$ världen. Carlssons, Stockholm.

SÖRLIN, S. (1988): Framtidslandet. Carlssons, Stockholm.

SOU (2004): Inlandet har möjligheter: slutbetänkande av Inlandsdelegationen. Statens Offentliga Utredningar 2004:135, Näringsdepartementet, Stockholm.

STORPER, M. (1997): The Regional World: Territorial Devel opment in a Global Economy. Guilford Press, New York.

SUNDBERG, N. and ÖSTRÖM, K. (1982): 'Migration and welfare, a study in Northern Sweden', Geografiska Annaler: Series B, Human Geography 64 (2): 153-160.

VAN DIJK, T.A.(1988): News as Discourse. Erlbaum, Hillsdale, NJ.

VOLOSINOV, V.N.(1986): Marxism and the Philosophy of Language. Harvard University Press, Cambridge, MA.

WALLANDER, J. (1948): Flykten från skogsbygden. En undersökning $i$ Klarälvsdalen. Industriens Utredningsinstitut, Stockholm.

WETHERELL, M., TAYLOR, S. and YATES, S.J. (2001): Discourse Theory and Practice: A Reader. Sage, London.

WODAK, R. and CHILTON, P. (eds) (2005): A New Agenda in (Critical) Discourse Analysis: Theory, Methodology and Interdisciplinarity. J. Benjamins, Amsterdam.

WOODWARD, R. (1996): “"Deprivation” and "the Rural": an investigation into contradictory discourses', Journal of Rural Studies 12 (1): 55-67. 


\section{APPENDIX}

NEWSPAPER ARTICLES

Dagens Nyheter (DN)

Article

VÄSTERBOTTEN

'Hälsokampanj gör sjukt län friskare'

'Stilla kabinfärd i ostens rike'

'10 tips i Västerbotten'

'Allt fler dör på Västerbottenvägar'

'Attrakiva tomter ger fler tvister'

'Över 60 bränder i Västerbotten'

'Jordskalv i Västerbotten'

'Framåt för s-kvinnor i Västerbotten'

'Guldrush i norr: lärare gräver guld i Västerbotten'

'Samisk offerplats kan bli reservat'

'Turistföreningens Västerbotten'

'På högfjället med liten ränsel'

\section{JÄMTLAND}

'Glesbygdsbor kan få mobil vård. Samhällsservice på hjul föreslås för Jämtlands avfolkningsorter'

'Fjällen bjuder på fäbodliv'

' 10 tips i Jämtland'

'Jämtland kan få ny storkommun'

'Miljonstöd till småskalig produktion'

'Norsk fotbollsstjärna satsar i Jämtlandsfjäll'

'4 Årebyar: Åre - snö för hela slanten'

'På fyra ben över fjället'

'Försäkringskassan: halverade öppettider i Jämtland'

'Fjälltrakter lockar med äventyr'

'Jippo värvar nya jämtar'

'Persson landar i "folkets paradis"'

'Tre frågor...'

'Östersund/måndag: Möte med trav och lek'

'Jämtland lockar med buller'

'Landskap, typ: Jämtland'

'På högfjället med liten ränsel'

\section{NORRBOTTEN}

'Persson lovar miljardsatsningar

'Norrbotten stoppar nya naturreservat

"'Sjukskrivning används som regionalstöd",

Lokala attityder ligger bakom den höga sjukfrånvaron

i Norrbotten, skriver ekonomiprofessor'

'Varför stannar männen kvar?'

'Kulturell jättesatsning där norrbottningen har huvudrollen'

'Analys kortade vårdköer

“"Gränsen nådd för partilojaliteten”. Kommunalråd (s) varnar Göran Persson: väljarflykt hotar i utarmat Norrbotten'

'Bakslag för ny järnväg i norr'

'Nya krav att Rosengren avgår'

'Varghona synlig i norr'

'Miniintervjun: första länsregissören går'

'Fler unga sjuka i Norrbotten

"Lönsamt med järnväg vid kusten",

'Centerkrav på jobb till Norrbotten'

'Vårdjobb inget för karlar i norr'

\section{Date}

3 July 2004

9 May 2004

9 May 2004

28 September 2003

24 July 2003

22 July 2003

25 April 2003

19 February 2002

18 January 2002

7 October 2001

26 November 2000

25 June 2000

24 May 2004

9 May 2004

9 May 2004

2 April 2004

19 Mach 2004

28 September 2003

19 January 2003

7 July 2002

12 July 2002

17 March 2002

14 March 2002

2 February 2002

30 November 2001

10 April 2001

25 February 2001

15 July 2000

25 June 2000

28 March 2004

31 January 2004

18 October 2003

17 June 2003

10 May 2003

25 April 2003

24 April 2003

9 January 2003

16 December 2002

14 December 2002

21 September 2002

1 September 2002

31 August 2002

28 August 2002

9 August 2002
Author

TT [Tidningarnas Telegrafbyrå, a

leading Swedish news agency]

Olle Säverman

TT

TT

TT

Tobias Hamma

TT

Olle Säverman

Sören Lövenhaft

Kari Molin

Hans Arbman

TT

TT

TT

Jan Malmborg, Olle Lindberg,

Bengt Erik Schöier and Helena Öberg

Helena Öberg

Eva Karin Gyllenberg

Ellin Wrethov

Christian Palme

Charlotta Eriksson

Thomas Michelsen

TT

Olle Säverman

Sören Lövenhaft

TT

Lars Ingemar Karlsson

Mats Persson

Maria Carlshamre

Nicholas Wenno

TT

Bengt Niska, Leif Nilsson and

Arne Honkamaa

Gunnar Jonsson

TT

Karin Bojs

Martin Stugart

TT

TT

TT

Irene Beertema 
MADELEINE ERIKSSON

'Utvecklingsbidrag betydde mycket'

'Landstinget i Norrbotten varslar'

'Norrbottenspartiet: med fasta steg mot Riksdagen'

'Norrbottenspartiet: "S-politik bäddar för Lars Törnman",

'Skidgymnasium läggs ned - trots ilskna protester'

'BB-kritiker får inte medhåll'

'Fem frågor'

'Norrbotten vill prova självstyre'

'S i norr vill förlänga Botniabanan'

'Norrbotten vill se unga företagare'

VÄSTERNORRLAND

'Hundratals nekas äldreboende'

NORRLAND

'Allt fler unga män lämnar glesbygden'

'Norrlänningar vill ha självstyre'

'Här stannar jag kvar'

'Protester mot flygförbud i norr'

"Stockholm en tärande region". Nya beräkningar visar att stockholmarna får mest av statens kaka medan norrlänningarna missgynnas

Stor export från övre Norrland

'Norrland slår tillbaka

'Stor älgstam hotar träindustrin

"LLandsbygdsfientliga s-toppar blåser till strid".

Forskare anklagar tunga politiker i Mälardalen för att sabotera regeringens glesbygdspolitik'

"Norrland måste få behålla stöd"'

'Norrlänningar får frågor om hälsan'

'Samarbete nödvändigt i Norrland'

'SJ: "Lämpligt börja i Norrland",

'Monopol och nedlagda tågförbindelser har fått näringsliv och offentliga organ att tröttna: "Hela Norrland säger nej till SJ",

'Ljusare tider i Norrland'

'Fler flygturer till Norrland'

'Nätverk stärker Norrlands inland'

'Miljöhänsyn hotar tillgång på virke i Norrland'

'Samarbete lösning för kultur i norr'

'Krav på regeringsansvar för Norrlandstrafik'

'Norrlandslän i kamp för fortsatt EU-stöd'

'Mål1-kassan töms redan i år'

'Vitbok i norr för fortsatt EU-stöd'

'Malmö Aviation vill flyga till Norrland igen'

'Regnet hotar elförsörjningen'
12 March 2002

10 January 2002

24 October 2001

24 October 2001

24 August 2001

10 August 2001

22 May 2001

15 May 2001

10 April 2001

8 April 2001

24 January 2000

26 August 2004

8 June 2004

28 April 2004

9 March 2004

16 February 2004

4 December 2003

21 November 2003

19 August 2003

18 July 2003

19 February 2003

8 February 2003

19 December 2002

14 December 2002

13 December 2002

6 December 2002

21 November 2002

26 September 2002

12 August 2002

3 July 2002

30 May 2002

6 May 2002

25 April 2002

12 April 2002

16 October 2001

11 September 2001
TT

Kristoffer Morén

Kristoffer Morén

Stellan Kvarre

TT

Peter Bratt

TT

TT

TT

Lena Karvik

TT

Henrik Berggren

Anita Sjoblom

Gerhard Larsson

TT

TT

TT

Ronny Svensson

TT

Bengt Falkloo

Maria Crofts

Monica Robin Svensson,

Gerhard Larsson,

Maggi Mikaelsson and others

TT

TT

TT

TT

TT

TT

Kristoffer Morén

TT

TT

Bengt Falkloo 